\title{
Impact of Culture on Entrepreneur Intention
}

\author{
Syed Imran Sajjad 1 , *Haroon Shafi ${ }^{1}$, Aasim Munir Dad ${ }^{2}$ \\ ${ }^{1}$ Iqra university Islamabad campus \\ ${ }^{2}$ University of Science and Technology (MUST) Mirpur Azad Kashmir, Pakistan \\ *haroonshafi4@gmail.com
}

\begin{abstract}
The main purpose of this study is to identify the role of entrepreneurship in Pakistan. After reviewing the literature, researchers identify those predictors who influence the entrepreneur's intention with the help of socio cognitive model. National culture of a country influences the entrepreneur's intention to start new business. Perceived feasibility, perceived desirability and entrepreneurs experience has a direct impact on entrepreneur's intention. The study finds out the impact of culture on entrepreneur intention, different cultures have different ways to influence the entrepreneur intention and different ways to impact on intentions towards perceived feasibility and perceived desirability .The study helps entrepreneur's decision making process and also helps out the development of further new business in Pakistan, motivates students to become entrepreneurs and analyzes their feasibility and desirability. Culture varies from country to country, within country different provinces, how different cultures, different traditions, norms and values. So in future, it helps to analyze entrepreneur's intention in different cultures.
\end{abstract}

Key words: Pakistan's society, Entrepreneurship, entrepreneur's experience, culture

\section{Introduction}

Entrepreneur is an individual who runs a business with new idea or adding value in existing idea entrepreneur is a creator, risk taker who brings change in environment, with the help of technology, effective organization trained employees, and gets maximum benefit. A good leader is that, who manage all these activities on continuous bases. This is the study of an individual who starts new business. In this paper researchers analyze the entrepreneurial intention how entrepreneur is being motivate to starts new business, the relationship between entrepreneur intention with their experienced and relationship between desirability that influences the entrepreneur intention, study also analyze the affect of national culture on entrepreneur intention as well as entrepreneurial activity for development and underdevelopment countries. Different aspects of human behavior but the one predictor intention plays an important role (Ajzen, 1991) when individual starts new business than an economic activity starts than circulation of money starts ultimately growth of country starts according to Romer(1994) due to entrepreneur investment in new venture long term growth of country starts.

According to Mitchell et al (2002) for starting a new business many factors influence entrepreneur intention like desirability, feasibility, and entrepreneurial experience, but it varies culture to culture and nation to nation, within country culture varies, researchers are still unclear, the over all impacts of culture in entrepreneur intention, Every country has its own culture, its values, norms and beliefs that affects the entrepreneurial intention, at some stages the culture plays an important role in decision making. Now a day's private sector plays a vital role in economic development, in private sector small business owners have various opportunities to start new venture. The policies of government are important for entrepreneurs, but only development of policies is not sufficient, their implementation is also mandatory to attract investor to invest in business, small and medium enterprises some time not going well due to lack of knowledge and infrastructure. This paper is conceptual in nature and focuses that how entrepreneurs motivate to start a new venture especially in the context of culture.

\section{Literature Review}


Entrepreneurial intention: Entrepreneurial intent to begin an innovative enterprise, in literature different researchers suggested the importance of entrepreneur intent such as (Shapero \& Sokol, 1982; Shapero, 1975; Krueger, 1993; Bird, 1988; Krueger et al., 2000). Some researchers including (Bird, 1988) identified entrepreneur individual nature, skill, experience the same as social desirability and personal feasibility. Different Researchers recommended including (Shane, 2003), that: the existence of an entrepreneurial possibility; its identification by the entrepreneur; and the conscious decision of the entrepreneur to be aware of that chance, are between the mandatory steps required in the entrepreneurial process. Cristina and Dwayne (2009) saw the effect of entrepreneur intention in Caribbean and the found out the link among entrepreneur intention, desirability, and feasibility and suggested that culture acted as moderator to influence the entrepreneur's intention. After reviewing literature it has been seen that there is linked between desirability perception and entrepreneur intention to begin a new venture, Krueger (1993) practiced Shapiro's theoretical model and suggested that there is a positive impact of perceived desirability on entrepreneur intention (Krueger et al., 2000). For better understanding of different indicators and the impact of these indicators on entrepreneur (Krueger et al., 2000) suggested that attitude of entrepreneur varies for every exogenous facet that affects entrepreneur intention to become entrepreneur.

\section{P1. Perceived desirability will directly influence entrepreneurial intentions.}

The study analyzed that perceived feasibility and perceived desirability are decided by exogenous facet for example individual and conditional facets disclosure to entrepreneur experiences that studied as exogenous facets, all these observation manipulate entrepreneur intentions. According to (Bandura, 1994) self-efficacy is an emotional and thinking process. In this, model the two predictor perceived feasibility and desirability act as mediators the both predictors influence entrepreneur experience. This paper is extensions of social cognitive process model that analyzed to identify, save, and recover the information ultimately take suitable action (Frese and Zapf, 1994). For entrepreneur information any resource is very important, to identify that information and take proper action. Cristina and Dwayne (2009) argued that perceived feasibility and desirability has direct impact on entrepreneur intention and also there is a direct relationship between entrepreneur experience and intention, entrepreneur, experience plays an important role, experience influences the intention, due to experience their performance increase, experience motivated towards risk taking for new venture .Due to entrepreneur expertise that is gained from previous experience makes strategies more effective (Zhao et al., 2005).

It has been argued that feasibility perceptions regarding entrepreneurship are influenced by prior exposure to entrepreneurial experiences. For example, (Shapero and Sokol, 1982) contended that prior exposure to entrepreneurial activity would have a positive effect on perceptions of feasibility (and perceived desirability). Krueger (1993) demonstrated in his study that breadth of entrepreneurial experiences significantly and directly influenced perceived feasibility, In literature it is carefully reviewed that entrepreneur's intentions reveal a very few piratical support such as (Krueger and Dickson, 1994), analyzed that in risky situation self efficacy of those entrepreneurs are high influence high level of perception, if feasibility is high then entrepreneurs intention is more to start a new business and desire to invest more and more in business. A supportive culture also influences the entrepreneur's intention, with his social and moral values and belief.

P2. Perceived Feasibility will directly Impact on entrepreneurial intentions

P3. Entrepreneur experience has a direct Impact on entrepreneurial intentions 


\section{Figure 1: Model}

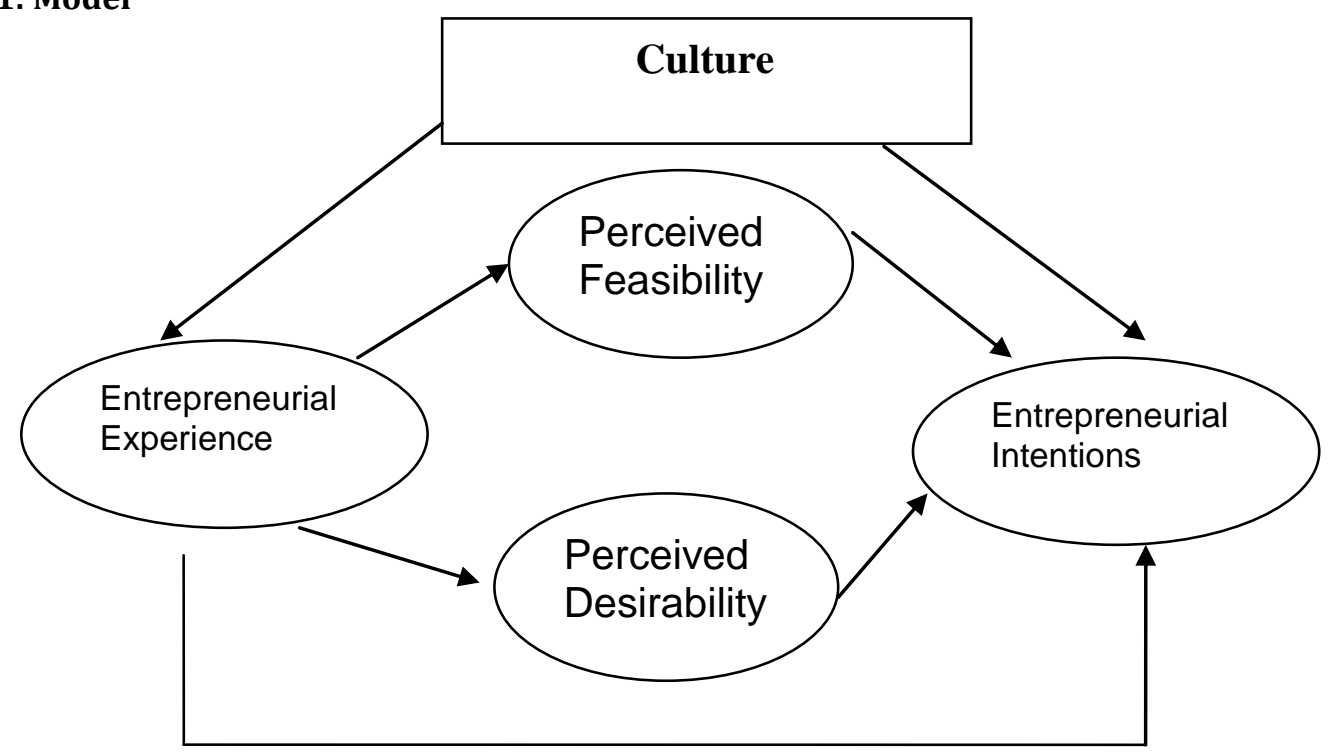

Culture: It recommends that the culture is most effective constant for entrepreneur. Good cultural values also influence the entrepreneur intention. The appropriateness, consistency, effectiveness, (ACE) model of persuasion (Reardon et al., 1989) three main thought of culture Importance, stability, efficiency. Culture includes some social, moral ethical values norms and beliefs that must be socially acceptable (Hofstede, 1980). This extends society think about those values norms and beliefs. Normally, researchers analyzed that culture facilitated the entrepreneurship because of high individuality, low ambiguity, and low in power remoteness, and high intention for commencement of new business. (Hayton et al., 2002, p. 34). National culture has a moderating effect on entrepreneur intention (Fernandez et al., 1997), George and Prabhu, 2000)

P4.culture of a country has a significant effect on entrepreneur intention.

\section{Discussion}

The present study examines the role of entrepreneurial intention in Pakistan and how culture affects the entrepreneurial intention. This model is based on Shapero and Sokol (1982) and tested by Krueger (1993). Later on Dwayne Devonish, et.al (2009) investigates the effect of entrepreneur intention in Caribbean; In Caribbean Governments are familiar with the need to expand the structure and change the mechanism in provinces and encourage the entrepreneurship. This present study sees the effect of culture in entrepreneurial intention in Pakistani society. Now - a - day's instability of government is not helpful for entrepreneur to invest. Government policies are also significantly affecting the entrepreneur intention. This model indicates that entrepreneurial experience has a direct and positive relationship with perceived desirability and perceived feasibility. The entrepreneurial intention plays an importance role for starting new venture, past experience influence their decisions the model shows the direct relationship between entrepreneurial intention and entrepreneurial experience. This model recommends that the entrepreneur's experiences acts as a key function to influence the intention of an individual to become entrepreneur linked with the previous point of view and research (Shapero and Sokol, 1982). According to Krueger et al (2000) experience influences the entrepreneur intention, there is also a direct relationship between entrepreneur's experience on perceived feasibility and perceived desirability, feasibility and desirability existing in environment that influence the entrepreneur's experience, so perceived feasibility and perceived desirability partially mediates entrepreneurs experiences and entrepreneurs intentions. Entrepreneurs experience directly influences the entrepreneur's intention to start a new venture. 
The other two indicators perceived feasibility and desirability mediated the entrepreneurial experience towards entrepreneurial intention. In this paper, we see the impact of culture on entrepreneurial intentions and his experience, how values and norms of a culture affect entrepreneurial decision in Pakistani society, different cultures have their own values traditions and norms, many small and medium size organizations have different impact on culture. Mark-Pruett et al. (2008) suggest that national culture of a country is directly linked with entrepreneur intention. Culture is shared values, norms, traditions rules beliefs, and anticipated behaviors of people. Cultural values and beliefs specify the level to which society judges' entrepreneurial behaviors, such as innovation, perceived feasibility, risk taking, independent thinking and perceived desirable.

Managerial implication: The study also helps managers to understand the impact of culture on entrepreneurial intentions and experience. The other motivating research would be to arrange a relative research for the service firms in different markets. A good culture influences entrepreneurial intention ultimately its performance increases and firm grows. A good supportive culture is helpful for the development of the organization, Government policies must be stable and supportive for new investors, banks also play important role for giving them loan on low interest rates, and all these aspects attract the entrepreneur intentions to start a new venture.

Limitation and Recommendation: The study finds out the impact of culture on entrepreneur intention, different cultures have different ways to influence the entrepreneur intention and different ways to impact on intentions towards perceived feasibility and perceived desirability. It is difficult to sketch the conclusion, because in both streams of researches, it is difficult to measure lack of agreement and lack of clearness. In conclusion, we can say that the involvement of culture and its influence on entrepreneurial intentions helps entrepreneur to take decision. The regular support is education that increases entrepreneurial performance and efficiency. It is suggested that the education system in universities and colleges should help to improve the skill and knowledge of students regarding entrepreneurship, and also focus the students attention to find out the their desirability and feasibility in the field on entrepreneurship, conducting seminar on entrepreneurship allow entrepreneurs to share the experience with students and motivate them. Danns and Mentore (1995) suggested that "entrepreneurial experience" helps the students to develop positive attitude and approach to start a new venture.

\section{Conclusion and Future Research}

Finally, entrepreneurship is a key factor for the development of any country. The current study focuses on the entrepreneur's intention, national culture of a country influences the entrepreneur's intention, perceived feasibility, and desirability and entrepreneurial experience directly influence the intention of any individual to start a new business. This study only emphasizes only Pakistani culture, and culture related policies and their implementation. In future research scholar will focus on one aspect of culture or one particular area. Culture varies country to country. Appropriate scale should be developed to empirically examine relations among above model.

\section{References}

Ajzen, I. (1991). Theory of planned behavior. Organizational Behavior and Human Decision Processes, 50(1), 179-211.

Bandura, A. (1994). Self-efficacy, in Ramachaudran, V.S. (Ed.). Encyclopedia of Human Behavior Academic Press, $4,71-81$.

Bird, B. (1988). Implementing entrepreneurial ideas: the case for intentions. Academy of Management Review, $13,442-449$.

Cristina, J. \& Dwayne, D. (2009). An exploratory study of competitive strategies among hotels in a small developing Caribbean state. International Journal of Contemporary Hospitality Management, 21(4), $491-500$.

Danns, G. K. \& Mentore, M. M. (1995). Race and economic power in Guyana: a study of the East Indians, in Ryan, S. and Stewart, T. (Eds), Entrepreneurship in the Caribbean: Culture, Structure, Conjuncture, University of the West Indies, Institute of Social and Economic Research, Trinidad and Tobago. 
Fernandez, D. R., Carlson, D. S., Stepina, L. P. \& Nicholson, J. D. (1997). Hofstede's country classification 25 years later. Journal of Social Psychology, 137(1), 43-54.

Frese, M. \& Zapf, D. (1994). Action as the core of work psychology, in Trandis, H. C., Dunnette, M. D. and Hough, L. (Eds), Handbook of Industrial and Organ.

George, G. \& Prabhu, G. (2000). Developmental financial institutions as catalysts of Entrepreneurship in emerging economies. Academy of Management Review, 25, 620-30.

Hayton, J. C., George, G. \& Zahara, S. A. (2002). National culture and entrepreneurship: a review of behavioral research. Entrepreneurship Theory and Practice, 26(4), 33-53.

Hofstede, G. (1980). Culture's Consequences: International Differences in Work Related Values, Sage, Beverly Hills, CA.

Krueger, N. \& Dickson, P. R. (1994). How believing in ourselves increases risk taking: perceived self-efficacy and opportunity recognition. Decision Sciences, 25(3), 385-400.

Krueger, N. (1993). The impact of prior entrepreneurial exposure on perceptions of new venture feasibility and desirability. Entrepreneurship Theory and Practice, 3, 5-21.

Krueger, N., Reilly, M. \& Carsrud, A. (2000). Competing models of entrepreneurial intentions. Journal of Business Venturing, 15(2), 411-32.

Mark-Pruett, R., Bryan, T., Francisco, L. \& Jerry, F. (2008). International Journal of Entrepreneurial Behaviour \& Research, 15(6), 571-594.

Mitchell, R., Smith, J. B., Morsem, E. A., Seawright, K., Peredo, A. M. \& McKenzie, B. (2002). Are entrepreneurial cognitions universal? Assessing entrepreneurial cognitions across cultures. Entrepreneurship Theory and Practice, 26(4), 9-32.

Reardon, T., Crawford, E. \& Kelly, V. (1989). Link between nonfarm income and farm investment in Africa households: Adding the capital marketing perspective. American journal of Agriculture Economics, 76 (5), 172-179.

Romer, P. (1994). The origins of endogenous growth. Journal of Economic Perspectives, 8(1), 3-22.

Shane, S. (2003). A General Theory of Entrepreneurship, Edward Elgar, Cheltenham.

Shapero, A. (1975). The displaced, uncomfortable entrepreneur, Psychology Today, 9(11), 83-8.

Shapero, A. \& Sokol, L. (1982). Some social dimensions of entrepreneurship in Kent, C. (Ed.), Encyclopedia of Entrepreneurship, Prentice-Hall, Englewood Cliffs, NJ, 72-90.

Zhao, H., Hills, G. E. \& Siebert, S. E. (2005). The mediating role of self-efficacy in the development of entrepreneurial intentions. Journal of Applied Psychology, 90(6), 1265-1272. 